\title{
Research on the Challenges for the Contemporary Higher Vocational English Education and Countermeasures under the Environment of Employment-Guided Approach
}

\author{
Haipeng Luo ${ }^{1}$ \\ ${ }^{1}$ Nantong Health College of Jiangsu Province,226000 China
}

\begin{abstract}
In this paper, we conduct research on the challenges for the contemporary higher vocational English education and countermeasures under the environment of employment-guided approach. Quality of higher vocational English teaching is related to the reputation of the college of vocational education and training quality, relating to cultivate advanced technology applied to adapt to the new situation requires the modern talents. Our proposed novel methodology enhances the performance of the traditional English pattern and helps optimize the teaching model as well.
\end{abstract}

Keywords: Higher Vocational English Education; Countermeasures; EmploymentGuided.

\section{Introduction}

Build reasonable personnel training mode is the goal of higher vocational education in our country. Higher vocational English teaching is an important part in higher vocational education, which can meet the different needs of different types of higher vocational talents of English. Quality of higher vocational English teaching is related to the reputation of the college of vocational education and training quality, relating to cultivate advanced technology applied to adapt to the new situation requires the modern talents. Higher vocational education is an important part of China's vocational education system, to meet the needs of the masses of the people to accept higher education, improve the quality, for the country to cultivate applied talents of high quality factory positive effect. As my stuffy further deepening of reform and opening up, increasing international communication, the status of English teaching in higher vocational education increasingly appears warbler. At present, our country is widely opened in higher vocational college English courses, and gradually turned to use English teaching mode, to improve the communication and application ability of importance to the students. However, the traditional pattern of higher vocational English teaching means, single, have not completely adapt to era has given higher vocational English teaching task. In view of the current higher vocational English teaching situation and existing problems of analysis, find out the countermeasures to solve difficulties and way out has become the important research content of higher vocational English teaching workers [1].

In the higher vocational English education work needs to be built on the basis of the particularity of higher vocational education and general sober comprehensive cognition. Compared with the average college English education, higher vocational English education of different has the following several aspects: first of all, the goal of training has a certain particularity. The training goal of higher vocational school is cultivated, vocational and technical talents for the society, that is to say, students should study hard at school with one or more professional skills. As higher vocational English teachers, to awake to realize higher vocational school education goals, not just to teach students to master the word grammar, more important is to teach students the language 
application and practice, especially the students in the field of professional related to the use of English. Second, in terms of curriculum, the higher vocational English courses generally low percentage, the less chance of students and the teacher communication, therefore, higher vocational music teaching should focus on main methods to teach students to learn to teach to fish, to cultivate the students' ability to study independently and to develop good study habits, methods and benefit the whole life. Third and moreover, the students, the ordinary university students after the college entrance examination strict screening, ability to learn, horizontal differentiation phenomenon is not obvious, but the higher vocational school students more extensive, in English learning, show obvious differentiation phenomenon, teachers should fully understand students' different learning levels [2].

Higher vocational English education is still relatively lagging behind the development of higher vocational education and there is a mismatch in the education idea and deviation. Understanding of the basic characteristics of higher vocational English teaching and its particularity, effect of English teaching is unable to fully meet the requirements of higher vocational training target. Therefore, should strengthen the research of higher vocational English teaching which will find out the crux of the problem and solution which will promote the building of specialty construction and reform.

To handle the mentioned challenges, in this paper, we conduct research on the challenges for the contemporary higher vocational English education and countermeasures under the environment of employment-guided approach. Because of higher vocational education in China starts late, analysis, from the perspective of talent training in higher vocational English education is relatively lagging behind the development of higher vocational education, there is a mismatch in the education idea and deviation, old teaching methods and teaching equipment backward, seriously affected the teaching effect. In the following sections, we will discuss the solutions in detail.

\section{Our Proposed Methodology}

The Principles of Higher Vocational English Education. Employment guidance is to point to the development of education in terms of what it should support the limit of what is a point to promote in order to meet the needs of society and build a highly efficient way of education higher vocational education from the essence of which is a kind of employment but not completely to the students' employment education yuan as the only index of the development of higher vocational education currently remote after the higher vocational education can not only acquire knowledge by limited to a single operation skills but to master the skills which can improve their quality of employment to a certain extent on the method and higher vocational education has certain development potential remote if only school set up some fixed professional course is no way to meet the requirements of cultivating students' sustainable development ability of the remote if the school only pay attention to the education of students' professional knowledge and ignore the public basic course for students of teaching and education yuan so trained students will be relatively quality not comprehensive and solid professional knowledge is not in the current employment situation this lack of comprehensive quality of students tend to appear at a remote so for our country's higher vocational education reform must fully understand its and wild the close relationship between employment guidance and metallurgy away. Cultivate a lot of English talents for our country which has made great contributions to the general development of our social economy. At present, higher vocational college English teaching, however, still follow the pattern of the exam-oriented education. With the market demand and deviated from the training objectives of higher vocational college. 
According to the characteristics of the higher vocational college students, and importance to the country in recent years on the cause of higher vocational education, English curriculum reform is especially important in higher vocational colleges. Through the study of the public English teaching of students, can let students lay a solid knowledge of the language, train the students' ability to use English in the practical work which can let students use English to communicate freely and access to relevant information in English, translation of English material, read some of the instruments and equipment related instructions and draft some common English letter, etc. So the employment oriented to public English teaching in higher vocational education is necessary and inevitable, and it is also a key point of the reform.

The Core Concepts of the Employmentguided Approach. Employment orientation refers to the education development and the limit of what clear about what support point. That is a kind of education of the main social demand oriented. Can say, the higher vocational education is the education of employment, but not to the students' employment rate as the index of the higher vocational education. After higher vocational education, students obtain employment ability should not be limited to only a certain skills, and should be about employment quality and a comprehensive concept of the future development potential. Higher vocational education is to cultivate the students' ability of sustainable development. Only depend on the range of the professional course is impossible. If only pay attention to the education of students with professional knowledge, professor of public basic course for students without, so can only produce some solid quality not comprehensive, professional students, and this kind of students in the current employment situation will appear. [3] Therefore, our country's higher vocational education reform should fully recognize the relationship with the "employment guidance".
The Drawback of the Current Teaching Model. Characteristics of higher vocational English education is that it can into a guide in order to develop English education, as a professional in the English education in the process of constantly improving the students' basic knowledge of English, oral English ability, English application ability and strain capacity which enables the student to in under the premise of meet the job requirements, continuously study, improve their comprehensive English qualities. But some in the process of English education in higher vocational colleges to imitate English curriculum mode of the undergraduate colleges, teaching material lack of management of occupational, will not be able to meet the needs of the students employment application. Classroom teaching basic knowledge of English is only responsible for delivery which does not take the improvement of students' comprehensive English ability, etc.

In general, the drawbacks and challenges could be summarized as the following parts. (1) Teaching environment. Continuous development in recent years, higher vocational colleges, students and teachers have been increased, but the teaching condition and facilities are not really keep up with the pace of progress. English class is mostly in the regular classroom, no projector, there is only the teacher, student, blackboard and chalk, better teacher will take a tape recorder to play your own English songs or audio let students exercise listening, but due to the limited class time will listen to only one or two times, so the foundation of the students don't effect, even if the school have a two English multimedia classrooms are only for the use of the English major students, the classroom is generally in the tireless teacher lectures, students can't understand also won't ask questions, just to play their own, the classroom effect is very poor. (2) Teaching assessment. Teaching evaluation is a test of students a good knowledge of the most effective way. But the way of the single 
evaluation method, blindly pursue knowledge scores, only pays attention to student's examination skills, to the lack of a systematic study in vocational skills and professional quality and evaluation. Some schools to take twice, divided into one and final, some schools even only for a final exam, and the teacher in order not to let students poor grades, a large proportion of the questions are given and make test scores for students to pursue the goal, the as long as the work on behalf of the English exam results have great adverse phenomenon, ignoring the English is a language, is used to communicate and work tools. (3) The choice of teaching material. Professional is the main characteristic of higher vocational colleges, it is different from general higher education the key, therefore higher vocational English teaching is to cultivate students the comprehensive ability of listening, speaking, reading and writing, and focus on training of English skills in daily work. At present, higher vocational English teachers completely according to the teaching material preparation, in accordance with the teaching materials to teaching contents in class, students are mainly materials to learn the basic knowledge, exercise level of English teaching is to students to master all of the main sources of knowledge of English, few students go to subscribe to English magazines or buy English extracurricular books. So choose suitable for higher vocational students' practical English and communication skills of English teaching is an important factor to improve students' English ability. (4) The teacher aspect. Higher vocational colleges along with the social demand for technical personnel of a large number of, its construction development, and constantly expand unceasingly, has formed a serious shortage of English teachers, the teachers and students proportion decline. So there was a teacher for hundreds of students in class at the same time, the phenomenon of because of too many students, the teacher don't consider the master degree of each student to the knowledge, then caused the fall of the quality of teaching, plus his workload every day, the teacher don't have enough time to prepares a lesson earnestly, also don't have time to participate in various training and practice to study teaching methods

The Solutions to the Mentioned Challenges. Teachers should influence the emotional factors of students learning behavior and learning effect. Moreover, we should use psychological theory and method, emotion teaching. In the teaching consciously is to inspire and mobilize students' positive emotional factors, so as to promote the improvement of students' overall quality and the development of personality. Under the new situation, the teaching requirements of college English have been changed, from the traditional reading primarily to give priority to in order to hear. Superior is currently emphasize oral articles, emphasizes the "original trace" teaching method. That is not emphasis on the language itself. Important is to speak English. The teacher in the classroom teaching which should leave the initiative to speak to the student, make them become passive to active. Negative to positive, truly become masters of learning. Through a lot of practice, cultivate students' ability to communicate in English, make students learn interested, productive, formed the ability of applying English communication. Our suggestions for the issues are summarized as the follows. (1) Through practice of diversified form rich teaching means. Successful English lesson taught how much content, it's not really important is to see how much students learn content, which can be used and how much. Teachers should change the bad habits scripted, understand and activate the teaching material, make the classroom full of fun, in the teaching time with students as the center, the place of the classroom as a communicative activity. (2) To carry out a variety of extra-curricular activities. Initiative aimed at higher vocational college students is poor, but the characteristics of active after class can organize students to watch English movies, English plays the rehearsal, buying English books, etc. Before watching the 
movies, the students on English vocabulary related to the movie and the cultural background, from all angles of the social let students understand foreign social humanistic amorous feelings, ethnic characteristics. (3) Write employment goal oriented English textbooks. A main feature of the higher vocational school is a professional it is the most difference with ordinary higher education for higher vocational school education, its main task is to try to improve the students' vocational ability for higher vocational English this subject is to actively cultivate the students' employment English application ability in higher vocational colleges must therefore reasonable use teaching materials for maximum and at the same time speed up to cultivate the students' professional English implementation as well as professional English teaching effect.

\section{CONCLUSIONS}

In this paper, we conduct research on the challenges for the contemporary higher vocational English education and countermeasures under the environment of employment-guided approach. With the rapid pace of China and the world, English has become a basic skill for students in high vocational school. Exist, however, the current English teaching in higher vocational colleges teaching and the market demand and jobs disjointed phenomenon, many students after graduation in work did not dare to speak or say a decent English comments. Higher vocational English teaching is to sublimation to a higher level, as the course of English teachers in a long way to go which not only have to clear the educational goal of higher vocational education, and according to the teaching reform which is the path to innovation in English teaching. Our method solves the challenges well.

\section{ACKNOWLEDGEMENT}

Sponsored by Qing Lan Project

\section{References}

[1] Wang H Y. On Several Problems in Higher Vocational English Education[J]. Journal of Education Institute of Taiyuan University, 2011.

[2] Liu X H. An Innovation of Competencebased Integrated Practice in Higher Vocational English Education[J]. Journal of Hubei Radio \& Television University, 2012.

[3] Feng J, Tang D. On Establishment of English Education Specialty and Construction of Its Curriculum System in Higher Vocational Education[J]. Journal of Hunan Radio \& Television. 